\title{
Perbedaan Efek Antibakteri Kapsul Minyak Bawang Putih (Garlic Oil) dan Kapsul Bubuk Bawang Putih (Garlic Powder) Terhadap Pertumbuhan Bakteri Staphylococcus aureus dan Escherichia coli Secara In Vitro
}

\author{
Ismail Fajri ${ }^{1}$, Erly $^{2}$, Elly Usman ${ }^{3}$
}

\begin{abstract}
Abstrak
Bawang putih telah diekstrak berupa kapsul garlic oil dan kapsul garlic powder sehingga dapat digunakan sebagai alternatif terapi dalam pengobatan penyakit akibat infeksi bakteri. Kandungan kapsul bawang putih yang memiliki efek anti bakteri adalah allicin. Bawang putih mempunyai efek anti mikroba dalam melawan bakteri Gram positif dan Gram negatif, diantaranya Staphylococcus aureus dan Escherichia coli. Di pasaran terdapat dua jenis kapsul bawang putih, yaitu kapsul bubuk bawang putih dan kapsul minyak bawang putih. Tujuan penelitian ini adalah menentukan perbedaan efek antara antibakteri kapsul minyak bawang putih dan kapsul bubuk bawang putih terhadap pertumbuhan bakteri Staphylococcus aureus dan Escherichia coli. Penelitian ini dilakukan di laboratorium Mikrobiologi Fakultas Kedokteran Universitas Andalas Padang dari Mei sampai Juni 2014. Jenis penelitian adalah eksperimental dengan menggunakan metode difusi cakram. Hasil penelitian didapatkan kapsul minyak bawang putih dan kapsul bubuk bawang putih tidak memiliki kemampuan untuk menghasilkan zona hambat terhadap bakteri Staphylococcus aureus dan Escherichia coli. Walaupun tiga kali pengulangan, tidak terdapat efek antibakteri pada kapsul minyak bawang putih dan kapsul bubuk bawang putih.Kesimpulan penelitian ini adalah kapsul minyak bawang putih dan kapsul bubuk bawang putih tidak memiliki efek antibakteri terhadap Staphylococcus aureus dan Escherichia coli.
\end{abstract}

Kata kunci: minyak bawang putih, kapsul bubuk bawang putih, Staphylococcus aureus, Escherichia coli

\section{Abstract}

Garlic extract in garlic oil capsules and garlic powder capsules can be used as alternative therapy in the treatment of diseases caused by bacterial infection. The content of garlic capsules which have anti-bacterial effect is allicin. Garlic has anti-microbial effect against Gram positive and Gram negative, including Staphylococcus aureus and Escherichia coli. In the market there are two types of garlic capsules, the capsules of garlic powder and garlic oil capsules. The objective of this study was to determine the differences of antibacterial effect between garlic oil capsules and garlic powder capsules on the growth of Staphylococcus aureus and Escherichia coli. This research was done in the laboratory of Microbiology, Faculty of Medicine, Andalas University, Padang in Mei to Juny 2014. The type of research is experimental by using the disc diffusion method. The results of this study, garlic oil capsules and garlic powder capsules do not have the ability to produce a zone of inhibition against Staphylococcus aureus and Escherichia coli. Although 3 (three) time repetitions, there were no antibacterial effect from garlic oil capsules and garlic powder capsules. The conclusion of this study is garlic oil capsules and garlic powder capsules do not have antibacterial effects against Staphylococcus aureus and Escherichia coli.

Keywords: garlic oil capsule, garlic powder capsule, Staphylococcus aureus, Escherichia coli 
Affiliasi penulis: 1. Pendidikan Dokter FK UNAND (Fakultas Kedokteran Universitas Andalas Padang) 2. Bagian Mikrobiologi FK UNAND 3. Bagian Farmasi FK UNAND

KorespondensI: Ismail fajri,Email : fajrie.i@gmail.com,Telp: $+628116641115$

\section{PENDAHULUAN}

Bawang putih (Allium sativum) adalah anggota dari keluarga Alliaceae telah diakui secara luas sebagai bumbu makanan dan obat untuk berbagai penyakit dan gangguan fisiologis. Bawang putih sebagai obat adalah untuk mencegah dan mengobati penyakit jantung dengan menurunkan tekanan darah dan kolesterol, antimikroba dan agen pencegahan untuk kanker. ${ }^{1}$ Ried et al di tahun 2008 dalam suatu penelitian menyatakan bawang putih yang telah di ekstrak berupa garlic oil dan garlic powder memiliki kelebihan dibandingkan bawang putih segar yaitu bau mulut dan bau badan yang minimal. Garlic oil dan garlic powder dapat digunakan sebagai alternatif terapi dalam pengobatan penyakit akibat infeksi bakteri. $^{2}$

Kandungan dari kapsul bawang putih yang memiliki efek anti bakteri adalah allicin. Zat ini dalam tubuh merusak protein bakteri penyakit sehingga bakteri penyebab penyakit tersebut mati. Banyak yang membandingkan zat ini dengan penisilin. Banyak yang menduga kemampuan allicin 15 kali lebih kuat dari penisilin. ${ }^{3}$ Beberapa studi menunjukkan bahwa bawang putih mempunyai efek anti mikroba dalam melawan bakteri Gram positif dan Gram negatif. ${ }^{4}$

Staphylococcus aureus (S. aureus) termasuk dalam klasifikasi bakteri Gram positif, sedangkan Escherichia coli (E. Coli) merupakan anggota bakteri flora usus normal manusia yang diklasifikasikan kedalam bakteri Gram negatif. Kedua bakteri merupakan flora normal manusia yang seringkali bersifat patogen dan menyebabkan penyakit yang menjadi masalah di masyarakat. ${ }^{5}$ Staphylococcus aureus masih menjadi salah satu dari lima penyebab paling umum infeksi nosokomial, sedangkan Escherichia coli adalah salah satu bakteri yang paling sering menyebabkan diare di seluruh dunia. ${ }^{6}$
Masalah yang timbul belakangan ini adalah semakin banyak bakteri yang resisten terhadap anti biotik. Staphylococcus aureus dan Escherichia coli termasuk bakteri multi drug resisten. Ankri dan Mirelman pada tahun 2007 melakukan penelitian mencari agen antimikroba yang efektif menghambat pertumbuhan bakteri multi drug resisten, melaporkan bahwa kandungan allicin dalam kapsul bawang putih mampu menghambat pertumbuhan bakteri tersebut. ${ }^{7}$

Kapsul bawang putih dalam bentuk olahan saat ini banyak tersedia di pasaran. Bawang putih yang dijual saat ini tersedia dalam bentuk kapsul minyak, kapsul bubuk dan tablet.

Penelitian mengenai efek antibakteri bawang putih sudah sangat sering dilakukan, namun belum ada penelitian yang menguji perbedaan efektivitas kapsul bawang putih sediaan oil dan powder. Berdasarkan latar belakang di atas perlu dilakukan penelitian untuk membandingkan perbedaan efek anti bakteri dari kapsul minyak bawang putih (garlic oil) dan kapsul bubuk bawang putih (garlic powder) terhadap pertumbuhan Staphylococcus aureus dan Escherichia coli.

\section{METODE}

Penelitian eksperimental ini dengan rancangan Post Test Only Control Group Design dan dilakukan tiga kali pengulangan dengan konsentrasi yang sama. Variabel adalah kapsul bawang putih dan bakteri. Sampel adalah kapsul bawang putih berupa kapsul minyak bawang putih dan kapsul bubuk bawang putih. Kapsul bawang putih ini merupakan produksi dari Griya An-nur dan Tazaka. Penelitian ini dilakukan di laboratorium Mikrobiologi Fakultas Kedokteran Universitas Andalas Padang dari April - Mei 2014.

\section{HASIL}

Penelitian telah dilakukan di laboratorium Mikrobiologi Fakultas Kedokteran Universitas Andalas mengenai perbedaan efek antibakteri antara kapsul minyak bawang putih (garlic oil) dan kapsul bubuk bawang putih (garlic powder). 
Tabel 1. Daya hambat antibakteri kapsul minyak bawang putih dan kapsul bubuk bawang putih terhadap Staphylococcus aureus

\begin{tabular}{ccc}
\hline Pengulangan & \multicolumn{2}{c}{ Besar Daya Hambat } \\
\cline { 2 - 3 } & $\begin{array}{c}\text { Kapsul minyak } \\
(\mathbf{m m})\end{array}$ & $\begin{array}{c}\text { Kapsul bubuk } \\
(\mathbf{m m})\end{array}$ \\
\hline 1 & - & - \\
2 & - & - \\
3 & - & - \\
Rata-rata & - & - \\
\hline
\end{tabular}

Tabel 2. Daya hambat antibakteri kapsul minyak bawang putih ( dan kapsul bubuk bawang putih terhadap Escherichia coli

\begin{tabular}{ccc}
\hline Pengulangan & \multicolumn{2}{c}{ Besar Daya Hambat } \\
\cline { 2 - 3 } & $\begin{array}{c}\text { Kapsul minyak } \\
(\mathrm{mm})\end{array}$ & $\begin{array}{c}\text { Kapsul bubuk } \\
(\mathrm{mm})\end{array}$ \\
\hline $\mathbf{1}$ & - & - \\
$\mathbf{3}$ & - & - \\
Rata-rata & - & - \\
\hline
\end{tabular}

Data hasil penelitian pada Tabel 1 dan 2 menunjukkan bahwa kapsul minyak dan kapsul bubuk bawang putih tidak memiliki efek antibakteri terhadap Staphylococcus aureus dan Escherichia coli.

Tabel 3. Diameter Daerah bebas pertumbuhan Staphylococcus aureus pada kontrol

\begin{tabular}{ccccc}
\hline & \multicolumn{3}{c}{ Pengulangan (mm) } & Rerata \\
\cline { 2 - 4 } & I & II & III & \\
\hline Ciprofloxacin & 27 & 27 & 27 & 27 \\
\hline
\end{tabular}

Tabel 4. Diameter Daerah bebas pertumbuhan Escherichia coli pada kontrol

\begin{tabular}{cccc}
\hline Kontrol/C & \multicolumn{2}{c}{ Pengulangan (mm) } & Rerata \\
\cline { 2 - 3 } & I & II III & \\
\hline
\end{tabular}

Ciprofloxacin
Hasil uji daya hambat menggunakan kontrol ciprofloxacin pada tabel 3, menunjukkan bahwa ciprofloxacin lebih efektif untuk membunuh Staphylococcus aureus dibandingkan kapsul minyak bawang putih maupun kapsul bubuk bawang putih.Pada tabel 4 hasil uji daya hambat menggunakan kontrol ciprofloxacin tidak ditemukan diameter daerah bebas pertumbuhan Escherichia coli karena bakteri yang digunakan pada penelitian bukan bakteri standar, tetapi bakteri yang didapatkan dari pasien.

\section{PEMBAHASAN}

Kapsul bawang putih merupakan produk olahan bawang putih yang diketahui memiliki efek antibakteri. Diketahui kandungan dari kapsul bawang putih yang memiliki efek anti bakteri adalah allicin. Zat ini didalam tubuh merusak protein bakteri penyakit sehingga bakteri penyebab penyakit tersebut mati. ${ }^{8}$

Mekanisme kerja zat antibakteri biasanya dimulai pada struktur sel terutama dinding sel. Dinding ini berperan untuk mengatur keluar masuknya zat seperti air dan garam-garam mineral yang dibutuhkan sel. Kerusakan pada dinding sel oleh zat antibakteri dapat mengakibatkan pertumbuhan sel bakteri terhambat bahkan mengakibatkan kematian pada sel bakteri karena organel-organel yang ada pada bakteri tersebut tidak dapat berfungsi. ${ }^{9}$ Allicin diketahui menghambat pembentukan protein di dinding sel bakteri, sehingga dapat mmenyebabkan cacat pada dinding sel bakteri yang akhirnya membuat bakteri tersebut mati karena system metabolism terganggu. ${ }^{10}$

Berdasarkan hasil penelitian yang peneliti lakukan, kapsul minyak bawang putih dan kapsul bubuk bawang putih tidak memiliki efek antibakteri terhadap Staphylococcus aureus dan Escherichia coli. Hasil penelitian membuktikan bahwa kapsul minyak bawang putih dan kapsul bubuk bawang putih tidak memiliki kemampuan untuk menghasilkan zona hambat terhadap bakteri Staphylococcus aureus dan Escherichia coli.

Tabel 1 dan 2 menunjukkan, bahwa dari 9 (sembilan) kali pengulangan tidak terdapat efek antibakteri pada kapsul minyak bawang putih dan kapsul bubuk bawang putih. 
Berdasarkan penelitian Andrews, kapsul minyak bawang putih memiliki efek antibakteri lebih tinggi dibandingkan kapsul bubuk bawang putih, mengingat bentuk sediaan padat zat aktifnya lebih stabil secara fisik dan kimiawi dibandingkan sediaan bubuk. ${ }^{11}$ Hipotesis ini tidak terbukti dari pengujian efek antibakteri kedua jenis kapsul bawang putih terhadap Staphylococcus aureus dan Escherichia coli tidak ditemukan diameter daya hambat dari kapsul minyak bawang putih terhadap bakteri tersebut. Hal ini dikarenakan kandungan antibakteri yang terdapat pada kapsul bawang putih mudah menguap sehingga kadar antibakteri pada kapsul tersebut menjadi berkurang. Produk kapsul minyak bawang putih yang di teliti belum bisa dikatakan efektif untuk membunuh bakteri karena belum memenuhi control zone diameter limits yang ada pada zone diameter interpretive chart.

Eksperimen untuk menilai efek antibakteri terhadap bakteri Staphylococcus aureus dan Escherichia coli ini memberikan perlakuan yang sama untuk kedua jenis kapsul bawang putih. Kedua jenis kapsul bawang putih memiliki konsentrasi 100\%. Hasil penelitian menunjukkan kapsul bawang putih tidak memiliki efek daya hambat terhadap bakteri.

Penelitian sebelumnya, dikatakan kapsul minyak bawang putih memiliki efek antibakteri yang lebih kuat dibandingkan kapsul bubuk bawang putih diakibatkan bentuk sediaannya yang cair. Sediaan yang cair memungkinkan zat aktif di dalamnya lebih stabil secara kimia. Kestabilan zat aktif ini akan cenderung menyebabkan efek yang diharapkan timbul lebih kuat. Ini didukung oleh pernyataan Andrews, ${ }^{11}$ bahwa bentuk sediaan cair diketahui memiliki suatu keunggulan jika dibandingkan dengan bentuk sediaan kering, yaitu bahwa dengan cairnya bentuk sediaan tersebut, maka bentuk sediaan tersebut lebih menjamin stabilitas kimia zat aktif yang terdapat di dalamnya. Dengan stabilnya sifat kimiawi allicin sebagai zat aktif yang berfungsi sebagai antibakteri dalam kapsul minyak bawang putih, tentu akan mengakibatkan efek antibakteri yang muncul lebih baik dibandingkan sediaan yang padat.
Kestabilan kimiawi zat aktif, bentuk sediaan juga mempengaruhi jumlah komponen zat aktif. Kapsul bubuk bawang putih kemungkinan mengalami penurunan jumlah komponen allicin ketika melalui proses menjadi bentuk kering. Diketahui sifat allicin yang mudah teroksidasi dalam proses pembentukan menjadi sediaan kering, sehingga komponen zat aktif kapsul bubuk bawang putih lebih sedikit dibandingkan komponen zat aktif kapsul minyak bawang putih.

Kapsul bubuk bawang putih dilarutkan pada penelitian ini. Tujuannya adalah untuk mendapatkan konsentrasi yang setara dengan kapsul minyak bawang putih. Menurut Andrews, ${ }^{11}$ Alasan kenapa kapsul bawang putih tidak memiliki efek daya hambat terhadap bakteri Staphylococcus aureus dan Escherichia coli dikarenakan dari segi produk belum memenuhi standar obat yang diteliti di laboratorium atau yang disebut dengan obat Pro Analisa (PA), jadi kandungan dari allicin dalam satu kapsul belum bisa ditentukan konsentrasinya. Dari segi struktur kimia allicin menyebabkan zat ini mudah menguap sehingga kadar maksimal allicin yang diharapkan tidak tercapai.

\section{KESIMPULAN}

Kapsul minyak bawang putih tidak memiliki efek antibakteri terhadap bakteriStaphylococcus aureus dan Escherichia coli.

Kapsul bubuk bawang putih tidak memiliki efek antibakteri terhadap bakteriStaphylococcus aureus dan Escherichia coli.

Tidak terdapat perbedaan efek antibakteri kapsul minyak bawang putih dan kapsul bubuk bawang putih terhadap pertumbuhan Staphylococcus aureus dan Escherichia coli.

\section{DAFTAR PUSTAKA}

1. Londhe VP. Role of garlic (allium sativum) in various disease. Journal of Pharmaceutical Research and Opinion. 2011;4(1):129-34.

2. Ried K, Frank OR, Stocks NP, Fakler P, Sullivian T. Effect of garlic: a systemic review and metaanalysis. BMC. 2008;8:13. 
3. Purwaningsih E. Manfaat bawang putih. Yogyakarta: Penerbit Exact Ganeca; 2007.

4. Tattelman E. Healt effects of garlic. Am Fam Physician. 2005; 72(1):103-6.

5. Jawetz E. Mikrobiologi kedokteran Edisi ke-23. Dalam: Olehelferia RN, et al, editor (penyunting). Jakarta: EGC :2004. hlm.266-73.

6. Rivlin RS. Historical perspective on the use of garlic. J Nutr. 2001;131(3supll):951-4.

7. Ankri S, Mirelman D. Antimicrobial properties of alicin from garlic. Journal of Pharmaceutical Research and Opinion. 2011;4(1):129-34.
8. Purwaningsih E. Manfaat bawang putih. Yogyakarta: Penerbit Exact Ganeca; 2007.

9. Piscitelli SC, Burstein AH, Welden N, Gallicano $\mathrm{KD}$, Falloon J. The effect of garlic supplement on the pharmacokinetics of saquinavir. Clin Infect Dis. 2002.34(2):234-8.

10. Southeast Michigan. Clinical infectious diseases. vol.53(12). Oxford University Press. 2011. hlm. 1215-22.

11. Andrews GP. Advances in solid dosage form manufacturing technology. Phil. Trans. R. Soc. A. 2007;365:2935-49. 